\title{
Cultivating Capital for High School Newcomers: A Case Study of an Urban Newcomer Classroom
}

\author{
Rabia Hos ${ }^{1}$, Kayon Murray-Johnson, Amy Correia \\ University of Rhode Island, RI, USA
}

\begin{abstract}
This qualitative case study examines how students in a high school newcomer program experience the development of social and cultural capital. Newcomer programs are created by K-12 schools with large influxes of refugees and immigrants. This case study data stems from a larger ethnographic study of a newcomer program at Georgetown High, an urban secondary school in the Northeast region of the United States. Using Bourdieu's (1986) social and cultural capital theory as a framework for the study we provide an overview of the literature on the importance of helping newcomers build social and cultural capital. Themes arising from the data as representations of the experiences of newcomers building capital and the role of the teacher in that development is explored further. The paper concludes with a discussion of implications of the case for research, policy, and practice.

Kewwords: newcomers, English learners, social and cultural capital, newcomer programs, case study.
\end{abstract}

\section{Introduction}

This qualitative case study examines how students in a high school newcomer program experience the development of social and cultural capital. Newcomer programs are created by K-12 schools with large influxes of refugees and immigrants. The programs shelter the 'newcomer English Learners (ELs)' for a period of time in order for them to develop English and academic language. Newcomers are "foreign-born students and their families who have recently arrived in the United States" (U.S. Dept. of Ed., 2017, p. 1). However, K-12 schools in the United States do not often address or support the building of newcomer students' social and cultural capital as a critical part of their transition to a new country and system. Social and cultural capital refer broadly to one's accumulated networks, relationships, knowledge and skills; they are invaluable resources for navigating success in educational and societal systems--and are the basis upon which economic capital (financial gain) is ultimately acquired (Kenna \& Russell, 2018). Because capital consists of networks that facilitate access to different resources (Bourdieu, 1977; Carr \& Incetas, 2018), in education, it is consistently cited as essential to the success of linguistically and ethnically diverse students (Brooks \& Karathanos, 2009; Liang, 2012; Niehaus \& Adelson, 2014); newcomers who have more access to social and cultural capital are more successful in educational attainment (Curry, 2001; Gándara, Rumberger; Maxwell-Jolly, \& Callahan, 2003; Hopkins, Martinez-Wenzl, Aldana, \& Gandara, 2013; Hos, 2016; Valenzuela and Rubio, 2018).

Despite the importance of social and cultural capital to newcomers' success, many schools seem to limit their schooling experiences to the remediation of English language proficiency (Estrada, 2014; Kanno, 2018; Alogali, 2018; Kustati \& Al-Azmi, 2018). There remains a significant lack of comprehensive policies that address the structural, economic, and linguistic factors for newcomers to build the necessary capital while in school, [capital] which could lead to building post-secondary economic capital and to equal participation in U.S. education (Noguera, 2004; Straubhaar, 2013; Tang, 2015).

A general lack of research on newcomer students compounds the issue of lack of explicit support for the development of their social and cultural capital. There is limited research to help us understand how newcomer groups engage with capital at school, how teachers might play a role in developing newcomers' social and cultural capital, or how the structure of a newcomer program within a school supports or inhibits the development of capital. It is clear that there is a "need to be more explicit about teaching certain unspoken American classroom rules, attitudes, and behavior" (Pollock, 2018) and "social capital in the form of relationships with teachers and staff also are key to immigrant students' success" (Lee \& Walsh, 2015). This case study is explored with the goal of helping to close gaps in the literature on how capital is developed for newcomers.

Our case study data stems from a larger ethnographic study of a newcomer program at Georgetown High, an urban secondary school in the Northeast region of the United States. We begin with a brief discussion of Bourdieu's (1986) social and cultural capital theory as a framework for the study and an overview of the

\footnotetext{
${ }^{1}$ Corresponding author; Assistant professor of TESOL/Bilingual-Dual Language Education. E-mail; rabiahos@uri.edu
} 
literature on the importance of helping newcomers build social and cultural capital. Next we describe the methods, case context and setting. Finally, we explore themes arising from the data as representations of the experiences of newcomers building capital, the role of the teacher in that development, the institutional challenges of that development, and conclude with a discussion of implications of the case for research, policy, and practice.

\section{Social and Cultural Capital As a Framework}

Bourdieu's (1986) social and cultural capital are important lenses for our work for two reasons: (1) the theory is often used alongside qualitative studies that aim for a rich description of the participant experience (Merriam, 2009) — and (2) as a critical theorist, Bourdieu emphasized ways in which knowledge and power are expanded through institutions such as schools. Bourdieu (1986) describes power in terms of different forms of capital, namely economic, linguistic, social, cultural, and symbolic. Capital is defined as: the aggregate of the actual and potential resources which are linked to possession of a durable network... or in other words, to membership in a group - and which provides each of its members with the backing of the collectivity owned capital (Bourdieu, 1986, p. 248-249). Economic capital refers to financial resources and income, but on its own, is not adequate to buy status; it relies on the interaction with other forms of capital such as social and cultural capital.

Social capital is defined as a set of lasting social relations, networks, and contacts. Social class is a large part of the mediation of thought and action here because social class allows individuals and groups to make advantageous choices in many areas, including education. It follows, then, that "those in higher-class groupings are more likely to realize the value of schooling both in the field of education and the occupational field, thus increasing the likelihood of reproducing their position" (Rudd, 2003, p. 7). Cultural capital consists of investment in sets of symbols and meanings reproduced by the dominant class of a society (Bourdieu $\&$ Passeron, 1977; Márque, Peña, Jones, Orange, \& Simieou, 2018).) and passed down, or reproduced, through generations, and is the knowledge that enables an individual to interpret various cultural codes. Cultural capital related to knowledge about educational choices, ways of navigating the education system and educational access is referred to as academic capital (St. John, Hu, and Fisher, 2011). Bourdieu (1986) asserts cultural capital exists in three distinct forms: "the embodied state--that is-- in the form of long-lasting dispositions of the mind and body, the objectified state, in the form of cultural goods (pictures, books, dictionaries, instruments, machines, etc.)...; and in the institutionalized state, a form of recognized credentials that is conferred (for example, educational qualifications). He claims as certain individuals enter the (education) field, they (consciously or otherwise) become more aware of the rules of the game. This growing awareness of rules--that is how to navigate schooling systems and institutions--reflects the acquiring of an embodied form of capital over time, which leads to the potential for individuals to gain institutionalized capital. The cycle of possessing, maintaining, and reproducing capital necessary for success in school and society is thus likely to continue, leaving those outside the dominant groups at a clear disadvantage.

Given Bourdieu's social and cultural capital framework, a newcomer program can be seen as a hierarchical network with the goal of helping newcomers to adapt to the American education system. Yet, many adolescent newcomers from low socioeconomic backgrounds start out at a disadvantage with respect to social and cultural capital in a United States context: their parents usually have little knowledge of how U.S. schools function, there are differences in schooling practices that are valued (based on cultural norms), and individuals may lack knowledge of their rights with respect to education (Bigelow, 2007). His work is also useful in exploring how secondary students in a newcomer program can build varied forms of social and cultural capital. Time is an essential component in the process of acquiring cultural capital in particular. Bourdieu (1986) notes capital is closely linked to culture, built over time, almost unconsciously and often, in the process of socialization. As such, those who acquire varied forms of social and cultural capital within a given system are likely to fare better than those who have not. Since newcomers in our study have "missed out" on years of schooling in the U.S. education system where capital is reproduced, it is both critical and necessary to explore their experiences with the development of embodied and institutionalized forms of cultural capital in particular-forms that are most likely to promote equitable learning opportunities for them.

\section{Building Capital: An Overview of the Literature}

For adolescent newcomers and their families, cultural capital may be defined as the meanings, knowledge, customs, achievements, and outlooks that are related to their social positions. Often, the focus of school practitioners and policy makers is defining what students lack and what their needs are (Straubhaar, 2013). In the case of newcomers, the focus remains on building English proficiency. However, the limited literature around groups like foreign born, non-native speaking individuals (e.g. adolescent newcomers), 
suggests social and cultural capital needs to be identified and possibly used alongside the formal education system to better support them in U.S. schools (Bigelow, 2007).

Scholars like Bigelow (2007) for example contend that if the focus shifted to students' strengths and assets, with a view to learning about the kinds of social and cultural capital they may bring from their own communities, it would yield success for all involved. Prior educational experiences (with the dominant culture within a newfound culture) will help newcomers to succeed because they would have acquired embodied cultural capital, which can be applied to new contexts (Curry, 2003). Curry's (2007) study for instance, noted students who had previous experience with schooling norms like expectations in a college writing class did well, while those students who had not had schooling experience in their home countries, struggled with understanding directions, assignments, and other core elements of a given class. Bourdieu's (1973) cultural reproduction and social reproduction undergird studies like these. He writes:

An educational system which puts into practice an explicit pedagogic action, requiring initial familiarity with the dominant culture, and which proceeds by imperceptible familiarization, offers information and training which can be received and acquired only by subjects endowed with the system of predispositions that is the condition for the success of the transmission and of the inculcation of culture... This consists mainly of linguistic and cultural competence and that relationship of familiarity with culture which can only be produced by family upbringing when it transmits the dominant culture. (p. 71)

While familiarity with the dominant culture is often rare for the adolescent newcomer and her/his family, scholars suggest linguistic capital can be effective in building cultural capital. According to Liang (2012), the ability to speak two languages is considered "linguistic capital" in the sense that Spanish is used to clarify and better understand the English language in ESL classes (p. 9-10). Teachers should allow for both languages to be spoken in ESL classes, and recognize the bilingual identities of students (Park, 2018, p. 394, Liang, 2012, p. 11). Integrating English and the students' native languages can be done by "recognizing children as experts in the classroom," linking primary discourse to academic discourse through the curriculum," "embedding reading instruction and materials in the diverse perspective of ELs," "implementing culturally responsive management styles," and "conducting unbiased assessments" (Mays, 2008, p. 416-417). In addition, it is important that teachers provide newcomers with resources to learn about both of their cultures, identities, and languages (Park, 2018, p. 394).

In some cases, capital passed down from immigrant or minority families to their children allows them to succeed in school. For example, researchers Ogbu \& Simmons (1998) and Suarez-Orozco (1987) have found that immigrant children usually have a more positive outlook with respect to the educational system and what their expectations are than do non-immigrant children. Others (e.g. Portes \& Rumbaut, 2001; Zhou \& Bankston, 1996) suggest that the ability of immigrant families to structure children's experiences according to the family's beliefs results in greater academic success. Bourdieu (1979) also emphasized the importance of parental cultural capital in children's school outcomes.

Given the benefits of social and cultural capital highlighted so far, research does confirm they work in tandem with each other, but student outcomes may be nuanced. Bigelow (2007) discovered that Somali adolescents may have a wealth of social capital in the form of community around them, but their lack of cultural capital in the form of knowledge and means to navigate the dominant cultural system often pose obstacles to achieving their educational goals. Her study's participant was part of a tutoring group and tried to make use of social capital from her Somali community to achieve academic success. Bigelow found that her participant had a very supportive family that wanted her to succeed in school, but success was still difficult as she and her family lacked the cultural capital required to navigate the educational system in the United States. Additionally, the rich social capital that Somali adolescents possessed within their communities was not accessed because they were not necessarily the kind of cultural capital that is valued in U.S. society.

The struggle to navigate the dominant cultural and linguistic system of the U.S. school system is also explored in Borden's (2014) research of the English Only movement and its impact on Hispanic students. Borden critiques language assistance program models that are structured to reinforce the linguistic and cultural hegemony of the dominant, English-preferred language and culture. As English Learners (ELs) are forced to assimilate to English and the U.S. school culture, their home cultures and languages are not valued in both implicit and explicit ways, like implementing an English-only curriculum with materials that are not culturally relevant. These actions lead to a reduction of bilingualism and self-esteem in students, which are contributors to the high dropout rate of ELs, particularly Hispanic ELs. When ELs drop out of school because they do not possess the embodied form of capital Bourdieu describes and the U.S. schools value, the students are also denied access to gaining the institutionalized form of cultural capital of earning a high school diploma (Borden, 2014). 
It appears if students are lacking in social capital, alongside embodied and institutionalized cultural capital, the level of success they are able to achieve is limited; thus, it also limits the potential for post-secondary success. According to Kao (2004), information rooted in the above mentioned forms of capital (e.g. information about "schools...effective teachers...how to apply to college...how to obtain financial aid for higher education," etc.) that knowledgeable parents, or parents who know other knowledgeable parents, hold is "crucial to student outcomes but not easily obtained" (p. 173). The result is that those who know the rules of the game do fare better in education.

Finally, one study completed by Gonzales (2010) helps indicate multiple ways in which social and cultural capital might influence student outcomes - and the sources that might foster them. The researcher explored the ways in which "school experiences shape [the] postsecondary outcomes" of undocumented immigrant students (p. 469) by comparing life stories of undocumented Latino students in California. Gonzales (2010) determined that "positively tracked" students were those that reported being in small classes (including some Honors and AP courses) and having positive relationships with teachers and college counselors (p. 475). On the other hand, students who were placed in larger, general track classes were labeled "negatively tracked" (p. 475). Findings concluded "positively tracked" students are set up for success because they "benefit from environments that foster learning and the development of school-based social capital" (p. 482). In this example, Noguera's (2004) conclusion is affirmed: counselors and teachers act as "gatekeepers and brokers who can either expand or constrict access to educational opportunities" (p. 181). The school and teacher support that students receive can contribute to (or detract from) their social capital and cultural capital in ways that greatly impact their future beyond school.

\section{Methods}

This qualitative case study explored the following questions: How do newcomer students experience the development of capital in a newcomer high school program? Yin (2009) outlines a case study applies when: (a) the study's focus is to answer "how" and "why" questions...and when the study focuses on contextual conditions. A case is essentially "a phenomenon...bounded by a certain context...in effect [it is] your unit of analysis" (Miles and Huberman, 1994, p.25). Our study of a newcomer classroom represents our unit of analysis. In terms of specific approaches to the case study, Thomas' (2012) typology of case study designs is useful. We have applied four broad categories he suggests case study researchers use to inform their work: subject (kind of case), purpose (why), approach (how) and process (structure of the case) (Thomas, 2012). Under these categories, Thomas further provides subcategories from which to choose. We chose to frame the study's subject category as a key case since it provides "a particularly good or classic example" (p.77) of the phenomenon--that is, a diverse newcomer group and experienced ESL instructor known for culturally responsive teaching approaches. Because we are trying to understand something with the intention of possibly making it better - in this case, facilitating newcomer students effectively, we consider the purpose to fit the subcategory of an instrumental case--what Thomas (2012) calls "a tool or means to an end" (p.98). In terms of approach, our design reflects an illustrative type of case, where we are getting inside the problem" (p.119), with a view to possibly shed light on promising solutions. Finally, under the category of process or structure we have employed a single case study, examining a unique situation, as against multiple cases.

\section{Research Sample}

Research participants for the study included 19 newcomer students: 13 boys and 6 girls, with ages ranging from 13 to 18 and their certified ESL teacher, Mrs. Smith. Participants were part of Georgetown High, an established urban school community in the Northeast region of the United States. While historically the region has been considered stricken with poverty in terms of demographics, its surrounding community has experienced a recent influx of refugees and immigrants. Accordingly, newcomer students in this study are "recent immigrants who have little or no English proficiency and who may have had limited formal education in their native countries" [for various reasons]. These students have needs that traditional English-as-a-second language (ESL) programs are usually not designed to address, such as support with literacy development and academic language development (Short \& Boyson, 2003, p. 3). Usually this is because they may have had limited formal education.

The newcomer program at Georgetown is transitional in nature, so that students spend one to two years acquiring English language, some academic content, then transition into mainstream classrooms. Most students were Burmese/Karenni refugees from Thailand, with several immigrants from Yemen and refugees from Nepal. While students' average four and a half years of school enrollment in their countries, these students' schooling experiences ranged from 0 to 6 years prior to entering the U.S. secondary school. Mrs. Smith identified as a white, middle class teacher, with eight years of English teaching experience in the United States and overseas. 


\section{Data Collection and Analysis}

Since context was critical to understanding the way Mrs. Smith made meaning of teaching newcomers, data were collected by way of observations, field notes, video recordings and interviews with teachers and students in the newcomer program at Georgetown High School. Merriam (1998) notes observation within qualitative case study research offers "a firsthand account of the situation under study" (p. 111). Hos (2016) conducted observations and wrote field notes of classroom observations over the course of one academic year. These in turn, provided a rich description of the participants' experiences, classroom dynamics and any background experiences relative to the engagement of newcomers in content and as learners. The use of video recordings captured complex interactions such as gestures, facial expressions, and nonverbal cues (Marshall \& Rossman, 2006; Miller \& Zhou, 2007). Video recordings were helpful to capture details that might be missed in field notes and observations (Lemke, 2007). Video recordings were referred to during data analysis to confirm field notes. Additionally, video recordings allowed repeated viewings during the process of analysis (Lemke, 2007). Finally, interviews with the teacher and students can elicit participants' descriptions of the meanings of their worlds (Kvale, 1996). Three hour-long, semi-structured interviews with the newcomer teacher and students were conducted throughout the academic year. In our study, interviews provided insights about students' perspectives, their experiences, and the teachers' perspectives and practices in the newcomer program. The data were analyzed as they were collected using grounded theory methods (Charmaz, 2014). We followed a threestage process to coding the data: open coding, axial coding, and selective coding (Strauss \& Corbin, 1998). The sensitizing concepts that we used for this set of data were social and cultural capital (Charmaz, 2014).

\section{Findings of the Study}

Our case study explored the research question how do newcomer students experience the development of social and cultural capital in a high school newcomer program? Themes arising from the case include institutional barriers and the development of capital, and teacher intervention/classroom (best) practice and the development of capital. Two sub-themes were also evident concerning teacher intervention: "teaching the rules of the game explicitly" and "safe, supportive space."

\section{Theme One: Institutional Barriers and the Development of Capital}

Although the newcomer program at Georgetown High was designed to provide a welcoming, safe haven for the students as they acclimated to U.S. education, the school, and learned English, field observations indicated some central elements proved unsupportive of many students' needs. One significant element was physical location/logistics and resources. Participants in the newcomer program were physically separated from mainstream students, which in turn, made it difficult for students to engage in the very kinds of interactions that might improve their English speaking skills, and acculturation to their new home. Newcomer students at Georgetown had no social or academic interaction with students in the mainstream, even during lunch time in the cafeteria. Segregating newcomers from their non-EL peers is also against the U.S. Department of Education's recommendations for language assistance programs (USDOE, 2017) and research around the negative impacts of segregating ELs from their non-EL peers (Borden, 2014). Observations and interviews indicated several of them longed for more interaction with the mainstream students and/or to attend a different school. For example, 18 year old Haoh noted in one interview: "I want to change my school. There are too many people in my school. I see some people ... playing in my math class. People don't speak English" (Informal conversation 6/15).

Other issues like physical space and placement became out-growths of the separation of the newcomer program. Haoh, for instance, was in a math class taught by a long-term substitute teacher who was not certified in math or ESL. The classroom was overcrowded and Haoh did not think he was being challenged. Excerpts from field notes of Hos (2016)'s observations speaks volumes about this issue:

The math class is taking a midterm exam today. There are 25 students in the classroom. It's a small class and students are packed to sit very closely around a u-shaped table. There aren't enough desks and seats for the students. The teacher did not prepare a printed test but is projecting on the SMART Board simple math questions from a website- mathdrills.com The teacher is numbering the test questions as he goes along and asks the students to number on their blank paper. Many students seem confused not knowing how to follow along without modeling, and some students like Haoh are bored because this is too easy. The teacher asks simple addition and subtraction questions. (Field notes, $1 / 27$ ) 
Students in the newcomer program were also challenged with inequitable resources - an issue which contributed to lack of development of social and cultural capital. Unlike their mainstream peers, they were taught by uncertified teachers. Georgetown ESL teachers in the newcomer program were assigned to teach subjects outside of their certification areas, which created frustration among them because they had no training and no curriculum to follow. As one ESL teacher (Ms. Harry) noted when she was asked to teach an art class for newcomers: "I have to teach art without any supplies or curriculum" (Field notes, 9/15). Those in the newcomer program were enrolled in multiple subjects like social studies, science, mathematics, and art, but they were taught solely by teachers who were not certified in these subjects. It is suggested that newcomer teachers coteach with certified content area teachers (Echevarria, Vogt, \& Short, 2008). However, teachers in the newcomer program were not provided collaboration and co-teaching experiences with certified content area teachers because of staffing limitations. As such, newcomers were denied access to grade level curriculum and content, a violation of U.S. Department of Education's recommendations for servicing ELs' language and content needs (USDOE, 2017). The impact of inequitable access was studied by Callahan and Shifrer (2016), who found that ELs language status significantly impacted their access to academic rigor and exposure in educational programs. The lack of exposure led to sustained achievement gaps between ELs and their non-EL peers.

Limited parental engagement added to the lack of student support and led to further lack of development of capital of newcomer students. Based on observations, there were no efforts on the part of the administrators to collaborate with teachers and students, with a view to engage parents in their children's education; little to no parent activities or initiatives to invite parents to the school were observed. According to Niehaus and Adelson (2014), school support is correlated to parent involvement, and parent involvement is correlated to the socialemotional state of ELs. These researchers found that parents of ELs "were more involved in their children's education when schools offered more support and outreach services to ELs and families" (Niehaus \& Adelson, 2014, p. 834). In addition, "ELs reported fewer social and emotional difficulties when their parents were more involved in their education" (Niehaus \& Adelson, 2014, p. 835).

Finally, interviews with the students in the newcomer classroom revealed that they did not have the knowledge of the U.S. education system that would allow them to make informed decisions for their future. When asked about goals for the future, all responded in the affirmative, which included graduating from high school and going to college. But, they were not aware of what they needed to do to graduate from high school and then go to college, which requires a high school diploma. Most emphasized the need to "learn English" and "go to college." Yet, these students were unaware of specific steps to take or specific guidelines that would affect their aspirations; namely, they were not aware that the content area courses they were taking without a properly certified teacher were not counting towards their high school graduation requirements. Newcomers' limited knowledge was a combination of them not having adequate embodied cultural capital and a lack of specific information from the school.

Based on the findings, school structure and administration were not designed to intentionally equip newcomers with opportunities to build social and cultural capital for academic success. Moreover, the design of the newcomer program itself was denying access for newcomers' development of institutionalized cultural capital because the students were not provided with properly certified teachers to make progress towards high school graduation.

\section{Theme Two: Teacher Intervention and the Building of Capital}

Teachers play a significant role in serving as a source of information for immigrant and refugee ELs (Hones \& Cha, 1999). Moreover, "novices can learn the practices of a particular group" through explicit teaching of the "rules of the game" (Curry, 2007, p. 544). Findings from our study indicated Mrs. Smith's approach to her students, and general classroom practice helped newcomers build cultural and social capital. Specifically, there is evidence that she aided in the building of embodied cultural capital. Newcomers gained knowledge and skills as it concerned navigating curricular and extracurricular/social elements of schooling in a U.S high school context. Mrs. Smith taught explicitly and drew on students' experiences, so that they were familiar with the rules of the game in their new context. Rules were associated with key social expectations and with academic support/foundational skills like English literacy. Beyond mere literacy foundations, she taught newcomers critical test taking skills—not just the what (literacy content), but the lifelong skill of the how. Her intervention reflected the essence of embodied cultural capital, since her teaching helped incorporate meaningful additional cultural practices and attitudes, alongside perceptions, knowledge and abilities newcomers could use in other U.S educational and societal contexts later on. Concerning evidence of her helping students build social capital, much of Mrs. Smith's explicit teaching was done through modeling and encouraging practice collaborations between newcomer students and their newcomer peers. Social capital is a product of being connected to networks of individuals (Bourdieu \& Passeron, 1977); thus, the classroom community can become 
a network of students from different backgrounds who help each other in building various forms of that very capital. We provide highlights of our findings on how Mrs. Smith's teaching practice helped build social capital and embodied cultural capital next.

\section{Teaching Rules of the Game Explicitly: Social Expectations}

Concerning a school's social expectations, Mrs. Smith covered several important topics with students during the first few months of school. These included: how to check out books from the library and how to choose books to read (Field notes, 9/30). She also covered how to ask the school sentries to unlock the bathroom doors (Field notes, 9/29), how to talk in the hallway and stairs (Field notes, 10/20), and what to do when we see a fight (Field notes, 10/20). In discussing these social behavior expectations, Mrs. Smith explained each clearly, modeled for students, and had them practice it so that they would be able to use it. In all of the social and behavioral expectations, Mrs. Smith modeled the acceptable etiquette, then allowed students to practice it during class meeting times every Wednesday morning. Mrs. Smith also supported the development of social capital through teaching students about conflict resolution and reinforcing appropriate social interactions: for example, asking them to say, "Thank you" and, "You're welcome" to each other, and encouraging them to solve problems respectfully amongst each other. These lessons of etiquette in context helped the newcomers to develop linguistic, embodied cultural capital, and social capital in a safe space.

\section{Teaching Rules of the Game Explicitly: Literacy Foundations}

Students in the newcomer classroom were also engaged in learning critical literacy skills. Mrs. Smith's approaches to doing so were explicit. She used a variety of different resources in the classroom, modeling and peer to peer practice of literacy content and skills and integrated classroom rotations that involved literacy practices. Her pedagogical approaches fostered the building of students' linguistic capital in the English language gradually, while also helping them accumulate social capital since they worked together consistently and built a network of relationships. Students also developed embodied cultural capital--for example, learning the idiomatic dispositions that would work in U.S English speaking contexts. For example, in teaching a mini lesson that led to a reading/writing activity, Mrs. Smith explored the idiom "take after." She first shared pictures of her own mother and her aunt that were taken in the 1990s.

Mrs. Smith: "this picture is very old, maybe some of you weren't in this world then. Who do I take after?" Students respond, "your mother". She says "Yes, I take after my mother and if you see my sister she looks like my father, she is blond, bigger than me, but I take after my mother."

Mrs. Smith: I want you to think about who you take after in your family? Somebody in your family that you look like, look the same. Stand up and ask three people, who do you take after? Walk around and ask three people. Let's go.

Haoh approaches ELT: Who do you take after?

ELT: I take after my mother.

Haoh to Sunita: Sunita, who do you take after?

Sunita: I take after my aunt. Who do you take after?

Haoh: I take after my father. (Video transcript, 1/18)

Using the pictures and her life as resources, Mrs. Smith modeled the meaning of the word with clarity. Next, lower level student Haoh watched and listened to the her, interacted with higher level peers to practice the words, and received feedback from Mrs. Smith. It encouraged Haoh (and others in the process) to take risks in practicing the new word in a safe space. The combination of social, linguistic and embodied cultural capital that students potentially built as a result of her classroom practices, can help them successfully transition into mainstream classrooms.

Literacy in the language is a critical component for the success of ELs. Mrs. Smith's classroom rotations in particular, encouraged independent reading, writing, partner reading and guided reading, which in turn helped build their literacy foundations and make progress in English language reading and writing. Again, the rotations also allowed students to work with each other cooperatively and consistently as they completed reading and writing tasks. Cooperative and consistent practice with the language foundations, context and structure of a new culture, access to caring teachers and academic resources lead to the potential for the development of social capital and embodied cultural capital in these students over time (Hopkins et. al., 2013). In addition, Albers, Hellermann, \& Harris (2007) found that peer collaborative learning supports the development of literacy for older learners. Older learners with limited literacy first need modeling by the teacher, practice with peers, and then start to participate with support and feedback from the teacher (Hellermann, 2007). 
As students progressed and the academic demands of state mandated state tests approached, Mrs. Smith consistently prepared students. For example, she would introduce sample speaking practice activities and exercises, so students become familiar with test formats and practice them together:

Essential Question for today is "How can we study for the [state ESL] speaking test?"

Mrs. Smith: this is the easiest part of the test. This is speaking. Let's read directions. Imagine we're having a conversation. I'm talking and you're responding. Sunita can you read number one?"

Sunita: What grade are you in?

Saleh: Tenth grade.

Mrs. Smith: Now ask someone at your table the questions on the page 32 [referring to the handout] Saleh: What year were you born?

Mohamed: 1991. How do you get to school?

Moeh: By bus. What food do you like?

Haoh: Chicken. Chicken curry is good. (Field notes, 4/11)

Mrs. Smith also reviewed how to answer multiple choice reading comprehension questions with her students:

Mrs. Smith: Let's do some practice for our English test. Please copy this [pointing to the

SMART Board] in your notebook. I want you to circle $a, b$, or c.

After students copy the questions and answer, Hasan goes up to read the first question and circle the answer choice.

I___ in English class yesterday.

a)is b) was c) am d) are

Hasan[reads]: I was in English class yesterday. [and circles the correct answer]

Mrs. Smith: How do we know it's "was," why is it not "is"?

Mohamed: yesterday

Mrs. Smith: right, because of yesterday here. So you circle one answer. If you circle two answers on a test, it is wrong. [she makes a cross ' $\mathrm{x}$ ' figure with her arms]. Be careful on your test, only circle one okay? (Video transcript, 1/20)

Mrs. Smith believed that knowing how to answer multiple choice questions was an important skill for her students. "I want them to be able to answer multiple choice questions. They need to be able to eliminate wrong answers and find the correct answer," she said (Informal conversation 1/20). The explicit teaching of test taking skills necessary for success on mandated tests, is especially critical for newcomers. It is an important support skill that can add to their cultural capital--particularly in the embodied form. Several may have never taken a multiple-choice test and need the exposure to the format of the test and how to best choose answers-that is, the rules of the game. However, Mrs. Smith's actions here also have implications for the development of newcomers' institutionalized capital. Arguably, when these students have honed the rules of the game (and built embodied cultural capital) for testing, they have a greater potential to do well. Standardized tests measure cultural capital, resulting in a measured ranked result - that of a certification or validation of achievement (a classic example of institutionalized capital).

Teaching Explicitly: Impact

As a result of the literacy practices implemented in Mrs. Smith's classroom, students were able to make improvements on reading and writing. Reports from the reading intervention software used in the classroom (called System 44), for example, showed reading progress. The reading inventory was conducted at the start of the new term in January and at the end of the year in June. Table (2) below indicates specific improvements made by each student, as it concerned their reading progress: 
Table 1.

Students' Reading Levels

\section{Student Name}

System 44 Number of Words Read in January
System 44 Number of Words Read in June

\section{Ray}

Libby

Moeh

Haoh

Ehan

Mark

Moew

Than

Phan

Laoh*

Saen

Dani

Perry

Sunita

Sunny

Kurung

Hasan

Saleh

Mohamed
57

69

57

57

57

95

115

45

69

N/A

23

45

N/A

69

69

57

57

69

69
172

202

160

160

192

319

319

137

202

N/A

91

160

91

202

202

172

184

160

202

The reading intervention, System 44, that was used in the newcomer classroom used HMH Phonics Inventory to assess decoding and sight word reading fluency. Based on the number of words read in January, most of the students were able to read at least one hundred words on an average by June, indicating a slow but steady progress. As seen in the table above, students like Mohamed, Hasan, Moew, Sunny, Sunita, and Mark who had previous literacy and formal education experiences, showed greater improvement than other students like Than and Saen whom did not have much formal schooling in their countries. As suggested in the literature explored earlier, it is likely that students with fewer years of formal schooling need more time to improve their academic literacy in reading. 
In addition to making progress and building cultural capital through activities around literacy reading and writing, students also made progress overall in English language proficiency. This improvement was apparent on the state English language assessment in May. While all of the students scored at the "beginner level" before working with Mrs. Smith, in less than one academic year, all but one newcomer student scored at the "intermediate level." Table 3 shows the English language proficiency level change as pre and post levels. The researchers had access to the post scale scores, but not the prescores:

Table 2.

Students' English Levels Before and After the State ESOL Language Test in May

\begin{tabular}{|c|c|c|c|}
\hline Student Name & $\begin{array}{l}\text { Level in September } \\
\text { (tested from previous } \\
\text { year/or intake assessment) }\end{array}$ & $\begin{array}{l}\text { Test Score Out of possible } \\
\text { score } 750 \text { (to be } \\
\text { proficient) }\end{array}$ & $\begin{array}{l}\text { Level in June (tested } \\
\text { during the current } \\
\text { academic year Spring) }\end{array}$ \\
\hline ELT & Beginner & 603 & Intermediate \\
\hline Than & Beginner & 593 & Upper Beginner \\
\hline Mohamed & Beginner & 644 & Intermediate \\
\hline Mark & Beginner & 638 & Intermediate \\
\hline Ray & Beginner & 616 & Intermediate \\
\hline Dani & Beginner & 624 & Intermediate \\
\hline Libby & Beginner & 613 & Intermediate \\
\hline Haoh & Beginner & 610 & Intermediate \\
\hline MWT & Beginner & 653 & Intermediate \\
\hline Saen & Beginner & 629 & Intermediate \\
\hline Hasan & Beginner & 638 & Intermediate \\
\hline Moeh & Beginner & 616 & Intermediate \\
\hline Phan & Beginner & 624 & Intermediate \\
\hline Sunny & Beginner & 622 & Intermediate \\
\hline Kurung & Beginner & 627 & Intermediate \\
\hline Perry & $\begin{array}{l}\text { Beginner (arrived } \\
\text { in January) }\end{array}$ & 635 & Intermediate \\
\hline Sunita & Beginner & 616 & Intermediate \\
\hline Saleh & Beginner & 605 & Intermediate \\
\hline
\end{tabular}


Results from students' tests show that all the students in the newcomer classroom moved from beginner to intermediate level, with the exception of Than who scored close to intermediate. This progress may not necessarily have prepared them toward transitioning into the mainstream education; however, it was a step toward building foundational skills. Through explicit teaching of reading, writing, test preparation Mrs. Smith allowed newcomers to accumulate linguistic and cultural capital (in embodied and institutionalized forms), while also allowing them to build social capital as they engaged in the school and worked cooperatively in the classroom.

\section{A Safe Support Space}

According to Dotson (2001), instilling cooperative learning, respect, trust, and empathy are part of development of social capital between the students and teachers in the classroom. Mrs. Smith's embodied these elements in her classroom, thus creating a positive environment and a safe haven for students. Students felt comfortable in the classroom environment as they were encouraged to work cooperatively and supported each other. Subsequently, observations indicated trust and friendship established between the students and the teacher helped students to accumulate social capital through the building of self-efficacy. Social capital is a product of being connected to networks of individuals (Bourdieu \& Passeron, 1977); thus, the classroom community can become a network of students from different backgrounds who help each other in building various forms of that very capital. A network based on trust is an important source for building social capital (Dimitriadou, 2006; Hopkins et. al, 2013). Solid examples of the way safety and support became embedded by-products of Mrs. Smith's teaching were consistently observed. One example is below of an older student helping his peer fill out a permission slip for an upcoming roller skating trip:

Than: "I don't have paper."

Mark: Let me get application for you.

He went to get an application but as there weren't any applications, so he came back. Then I [the researcher] went to the office for some permission forms. Mark worked with Than to help him fill out the permission form. He pointed to the signature area and said: "Your mom sign this!" (Field notes, 3/11)

In this example, Mark, who had more formal education and literacy, was able to help Than to fill out a required permission form, a type of social and cultural capital needed to participate in the social practices of school. While this demonstrates peer support and safety leading to collaboration, it also indicates a leveraging of capital to support a classmate. Hence, demonstrating that capital can be transmitted.

\section{Discussion and Implications}

Findings from this case study under the themes "institutional barriers" and "teacher intervention" highlight two important issues as it concerns to how students might develop capital in schools--in our case, specifically social capital and institutionalized and embodied forms of cultural capital: (1) school structures and systems tailored to the unique needs of newcomers can play a significant role in inhibiting the access to the building of varied forms of capital; and (2) classroom teachers can make a difference by explicitly teaching newcomers cultural and social capital within a safe space to make academic gains.

Concerning school structures and systems, although the newcomer program at Georgetown High School may have had some positive aims and benefits concerning newcomers acclimating to the U.S education system, keeping newcomers in isolation from their mainstream English-speaking peers did not help with the development of social and cultural capital necessary for U.S. school success. Researchers have noted isolation in newcomer programs can be detrimental to newcomers (Faltis \& Arias, 2007). For example, physical and social segregation of ELs in addition to class and ethnic lines is a problem for these students (James, 2018; Orfield, Frankenberg, \& Lee, 2003). Such separation has contributed to the lack of exposure of the social and cultural capital valued in U.S. schools. Friedlander (1991), in his observation of the nature of newcomer programs, highlighted this issue well. We find his observation might also suggest a tension schools may also struggle with in their bid to help newcomers' transition as comfortably as possible. He argues that (by separating them), newcomer programs "place students in a drastically different education climate" (p. 1). Although this climate may be necessary to provide a comfortable environment for the newcomers, there should also be an effort to immerse them in the mainstream school culture.

Newcomers need ample opportunities beyond the newcomer program and sheltered content classes to be able to improve their linguistic and academic proficiency in order to build the necessary social and cultural capital (Hos, 2016). Beyond a verbal welcome and a designated classroom, a school's structure, system, staffing and resources need to be intentionally designed to facilitate newcomers' building of social and cultural capital that aids educational success beyond the high school--and to ensure equity among all students in the process of schooling. 
Because newcomers at Georgetown did not have certified subject area teachers, grade level curricula and adequate knowledge of matriculation processes that would allow them to develop institutionalized forms of cultural capital, newcomers were denied the rights afforded to them by the U.S. Department of Education's Office of Civil Rights. Districts are required to offer ELs equitable resources, which include adequate and appropriate curricular materials and properly trained staff, if the district receives federal funding (USDOE, 2017). The linguistic, physical and social separation experienced by newcomers at Georgetown also implies reduced access to rigorous teaching practices and curricula, and the creation of an unequal education playing field for the students.

Despite the systematic barriers to newcomers' development of social and cultural capital at Georgetown, this study also found teachers' positive intervention can make a difference. Explicit teaching of the rules of the game, promotion of a collaborative environment and ethics of care can foster the building of varied forms of social and cultural capital and is consistent with the literature (e.g. Hos, 2016). As Mrs. Smith used strategies like these to interact with newcomer students, she contributed positively to their sense of belonging and laid foundations for building the social and cultural capital necessary for success within the confines of the newcomer program. She helped students acclimate to their U.S school environment and build self-efficacy, enabling them to begin to become independent learners. Feinberg (2000) states, "how students feel about themselves as learners can have an important impact on their success in school" (p. 223). Routines in the classroom allowed students to build trusting relationships and safety, and the newcomer classroom served as an important buffer for ELs to adapt to an American school. The establishment of trust and respect in the classroom were important cornerstones of social and cultural capital (Wagner \& Gimenez, 2008). Trust and respect are the foundation for building a positive classroom environment, [and is] therefore a critical component in "engaging students academically and keeping them in school" (Gibson \& Bejinez, 2002, p. 159). We contend that the positive environment she Mrs. Smith created, helped build the foundation for students to accumulate some necessary social and cultural capital, and Mrs. Smith's practices of creating a welcoming and safe environment aligns with the recommendations set forth by the U.S. Department of Education's Newcomer Tool Kit (USDOE, 2017).

Alongside the implication that teaching interventions can yield some success for newcomer students in terms of building varied forms of capital, it is important to note that Mrs. Smith's intervention helped students build capital despite the major barriers evident in the institution as a whole. Although the findings are a result of one case, they (re) affirm the critical role teachers can play in helping students build capital. In this sense, our findings layer each other in understanding how newcomer students experience capital. Offering a newcomer program within a school is not sufficient enough to build newcomers capital (theme one). But, what happens within that newcomer program, in our case, positive teacher intervention can make a difference (theme two). In fact, scholars questioning ELs schooling issues continue to highlight the importance of positive relationships with teachers, development of self-esteem, and value of cultural/linguistic backgrounds to be successful in school (e.g. Borden, 2014) — elements that seemed to embody Mrs. Smith's practice. We argue findings like these may also be encouraging for institutions with limited staffing resources, due to budget limitations or other diverse learning settings (community based classrooms for example) where ESL teachers hope to make positive change for newcomers and similar groups through the building of capital.

An Emerging Form of Capital?

Despite the many barriers that the newcomers were faced with, we believe that a distinct form of cultural capital that is not spoken of in Bourdieu's theory became apparent as students spoke of their high aspirations. The students' resilience built through their difficult life experiences, arguably became a form of cultural capital. Immigrant and refugee student resilience is supported in the literature as a unique skill that can be converted into academic cultural capital (OECD, 2015; Trueba, 2002). Resilience is seen as a strong asset for refugee and immigrant students because of the hardships they may have experienced in life; these experiences may result in them working harder to achieve higher education (OECD, 2015; Trueba, 2002).

\section{Recommendations and Conclusions}

In light of our findings and implications, we offer a few recommendations for practitioners and policymakers, and conclude with two for further research. First, schools that implement newcomer programs need appropriately trained and certified faculty to support English language development and content area skills for newcomers. If appropriately trained and certified teachers work with newcomers, program developers also must ensure that newcomers have access to rigorous content. Ideally, teachers would be certified in both a content area and Teaching English to Speakers of Other Languages (TESOL), so districts would be able to provide credit towards a high school diploma while building students English Language Proficiency and content area skills. "One measure of whether ELs are able to attain equal participation in the standard instructional 
program within a reasonable length of time is whether a beginner EL will be able to earn a regular high school diploma in four years. ELs in high school, like their never-EL peers, should also have the opportunity to be competitive in meeting college entrance requirements" (USDOE, 2017). However, if the newcomer teacher is not certified in a content area, or the content area teacher does not have TESOL training, then a co-teaching model could be put in place to provide access to grade-level appropriate content while developing English language proficiency. Measures like these put in place promote equity and access for all students and would support the potential for newcomers to develop institutionalized capital.

Second, we believe it is critical for stakeholders at every level of a school to grant meaningful opportunities for newcomers to interact with native English-speaking peers. While we understand there may be some initial sheltering in newcomer programs as students adjust to life in a new place, newcomer programs must minimize segregation from non-EL peers to provide access to native language speakers and mainstream curriculum. Program developers at the local school level, for instance, might consider creating a buddy system between EL and non-EL peers that helps to provide newcomers with more exposure to mainstream students and school activities. At the classroom level, teachers must provide a safe, supportive environment where newcomers have the opportunity to practice language with their non-EL peers, so they can build English language skills alongside the building of their social and cultural capital.

Third, creating a rigorous transitional plan that helps leverage the social cultural capital and skill sets newcomers do possess, while offering language-rich acquisition of the kinds of social and cultural capital needed for navigating U.S schools is critical for these students to become successful and contributing participants in society. Such a transitional plan should involve significant amounts of collaboration among teachers, counselors, administrators, parents, and students. For example, we suggest that a liaison (member of staff, teacher or community member) could act as a point person - alongside a few others that form a committee to coordinate what the individualized transition plan might look like in order to get all stakeholders involved in the decision making. For example, the team could decide when newcomers could transition into sheltered content area classes or mainstream classes, perhaps by staggering transition by each content area, an individual learning plan could be developed for teachers to document strengths and needs for the student's language domain (speaking, listening, reading, writing) and how to support the newcomer through accommodations or modifications of assignments and assessments.

Finally, we recommend that further research be conducted with newcomer students in a variety of school contexts, for example multiple case studies and longitudinal research that could better capture how students engage with and utilize capital for success within varied levels of U.S. schooling systems. This case study highlighted that a teacher can make a difference in developing capital in newcomers, but further research should be conducted to analyze various structural and programmatic supports for newcomers outside of the teacher's walls. Additionally, tracing newcomers into postsecondary settings would help researchers learn how the development of social and cultural capital impacted future economic gains (i.e. transferred into economic capital). Newcomer ELs remain an overlooked or undervalued population in U.S. school contexts (Farbman, 2015). Moreover, with the currently shifting demographic both in the U.S and in other parts of the world, more of this kind of research will be needed to advance what we know about equipping institutions and teachers to become more culturally responsive and more equitable in their facilitation of all student groups, particularly newcomers. With the increased migration stimulated by political unrest in different parts of the world, the integration of newcomers into the host society is a pressing issue in not only the United States but in highest migrant and refugee hosting countries such as Canada and Germany, too. It is important to recognize that the development of social and cultural capital as a powerful tool for both the newcomers and the host society. There is a global need for research to understand how newcomers can develop cultural and social capital, so they can attain success within their new society.

\section{References}

Albers, S., Hellermann, J., \& Harris K. (2007). A case of a student with little prior formal education: Success and interactional practices in the language classroom. Proceedings of the third annual forum for loweducated second language and literacy acquisition: Research, policy, and practice, 109-124.

Alogali, A. (2018). World Englishes: Changing the Paradigm of Linguistic Diversity in Global Academia. Research In Social Sciences And Technology, 3(1), 54-73. Retrieved from http://ressat.org/index.php/ressat/article/view/342

Bigelow, M. H. (2007). Social and cultural capital at school: The case of a Somali teenage girl. Literacy Institute at Virginia Commonwealth University, 7-22. Retrieved from http://citeseerx.ist.psu.edu/viewdoc/download?doi=10.1.1.513.8670\&rep=rep1\&type=pdf 
Borden, R. S. (2014). The English Only Movement: Revisiting Cultural Hegemony. Multicultural Perspectives, 16(4), 229-233. doi:10.1080/15210960.2014.956607

Bourdieu, P. (1973). The three forms of theoretical knowledge. Information (International Social Science Council), 12(1), 53-80. doi:10.1177/053901847301200103

Bourdieu, P. (1977). The production of belief: Contribution to an economy of symbolic goods. Media, Culture, and Society, 2, 261-293. doi:10.1177/016344378000200305

Bourdieu, P. (1979). Symbolic Power. Critique of Anthropology, 4(13-14), 77-85. doi: $10.1177 / 0308275 \times 7900401307$

Bourdieu, P. (1986). The forms of capital. Cultural theory: An anthology. Wiley-Blackwell.

Bourdieu, P. (1998). Practical reason: On the theory of action. Stanford: Stanford University.

Bourdieu, P., \& Passeron, J. C. (1977). Reproduction in education, society, and culture. London: Sage.

Brooks, K., \& Karathanos, K. (2009). Building on the cultural and linguistic capital of English learner (EL) students. Multicultural Education, 16(4), 47-51. Retrieved from http://uri.idm.oclc.org/login?url=http://search.ebscohost.com/login.aspx?direct=true \&db=eft\&AN=50 8077498\&site=ehost-live \&scope $=$ site

Callahan, R. M., \& Shifrer, D. (2016). Equitable Access for Secondary English Learner Students: Course Taking as Evidence of EL Program Effectiveness. Educational Administration Quarterly, 52(3), 463-496. https://doi.org/10.1177/0013161X16648190

Carr, E. R., \& Incetas, Y. (2018). Perceptions \& Experiences of Non-Muslim Minority Students $\quad$ on the Muslim Image. Journal of Ethnic and Cultural Studies, 5(2), 43-52.

Charmaz, K. (2014). Constructing grounded theory, Second Edition. Thousand Oaks, CA: Sage Publications.

Curry, M. J. (2001). Adult ESL students in the contact zone: Exploring the effects of multiple educational attainment levels on the community college writing classroom. Retrieved from https://eric.ed.gov/?id=ED454706

Curry, M. J. (2003). Skills, access, and 'basic writing': A community college case study from the United States. Studies in the Education of Adults, 35(1), 5-18. Retrieved from http://uri.idm.oclc.org/login?url=http://search.ebscohost.com/login.aspx?direct=true \&db=eft\&AN=50 7822046\&site=ehost-live \&scope $=$ site

Curry, M. J. (2007). A "head start and a credit": Analyzing cultural capital in the basic writing/ESOL classroom. Pierre Bourdieu and literacy education, 291-310. Routledge.

Dimitriadou, A. (2006). Formation of social capital for refugee students: An exploration of ESOL settings in two further education colleges. The Journal of Doctoral Research in Education, 4(1), 31-45.

Dotson, J. M. (2001). Cooperative learning structures can increase student achievement. Kagan Online Magazine, Retrieved from: https://www.kaganonline.com/free_articles/research_and_ rationale/ increase_achievement.php

Echevarria, J., Vogt, M., \& Short, D. J. (2008). Making content comprehensible for English learners: The SIOP model. Pearson.

Estrada, P. (2014). English learner curricular streams in four middle schools: Triage in the trenches. Urban Review, 46, 535- 573.

Faltis, C., \& Arias, B. (2007). English language learners task force: A response to the proposed structured English immersion models. ELL Task Force Hearings.

Farbman, D. A. (2015). Giving English language learners the time they need to succeed profiles of three expanded learning time schools. The National Center on Time \& Learning (NCTL). Retrieved from https://www.timeandlearning.org/sites/default/files/resources/ell_report_12.14.15.pdf

Feinberg, R. C. (2000). Newcomer schools: Salvation or segregated oblivion for immigrant Students? Theory Into Practice, 39(4), 220-227. doi:10.1207/s15430421tip3904_5

Friedlander, M. (1991). The newcomer program: Helping immigrant students succeed in U.S. schools (Program Information Guide No. 8). Washington, DC: National Clearinghouse for Bilingual Education.

Gándara, P., Rumberger, R., Maxwell-Jolly, J., \& Callahan, R. (2003). English learners in California schools: Unequal resources, unequal outcomes. Education Policy Analysis Archives, 11(36). doi:10.14507/epaa.v11n36.2003

Gibson, M. A., \& Bejinez, L. F. (2002). Dropout prevention: How migrant education supports Mexican youth. Journal of Latinos and Education, 1(3), 155-175. doi:10.1207/S1532771XJLE0103_2

Gonzales, R. G. (2010). On the wrong side of the tracks: Understanding the effects of school structure and social capital in the educational pursuits of undocumented immigrant students. Peabody Journal of Education, 85(4), 469-485. doi:10.1080/0161956X.2010.518039 
Hellermann, J. (2007). The development of practices for action in classroom dyadic interaction: Focus on task openings. The Modern Language Journal, 91(1), 83-96. doi:10.1111/j.1540-4781.2007.00503.x

Hones, \& Cha. (1999). Educating new Americans. New York: Routledge.

Hopkins, M., Martinez-Wenzl, M., Aldana, U.S., \& Gandara, P. (2013). Cultivating capital: Latino newcomer young men in a U.S. urban high school. Anthropology \& Education Quarterly, 44(3), 286-303.

Hos, R. (2016). Caring is not enough: Teachers' Enactment of Ethical Care for Adolescent Students with Limited or Interrupted Formal Education (SLIFE) in a Newcomer Classroom. Education and Urban Society, $48,479-503$.

James, G. (2018). A narrative inquiry perspective into coping mechanisms of international postgraduate students' transition experiences. American Journal of Qualitative Research, 2(1), 41-56.

Kanno, Y. (2018). High-performing English learners' limited access to four-year college. Teachers College Record.

Kao, G. (2004). Social capital and its relevance to minority and immigrant populations. Sociology of Education, 77(2), 172-183. doi:10.1177/003804070407700204

Kenna, J., \& Russell III, W. (2018). The Culture and History of Standards-Based Educational Reform and Social Studies in America. Journal of Culture and Values in Education, 1(1), 26-49. Retrieved from http://cultureandvalues.org/index.php/JCV/article/view/2

Kustati, M., \& Al-Azmi, H. (2018). Pre-Service Teachers' Attitude on ELT Research. Research in Social Sciences and Technology, 3(2), 1-13. Retrieved from http://ressat.org/index.php/ressat/article/view/47

Kvale, S. (1996). Interviews: An introduction to qualitative research interviewing. CA: Sage Publications.

Lee, S. J. (1996). Unraveling the "model minority” stereotype. New York: Teachers College Press.

Lee, S. J., \& Walsh, D. (2015). Welcoming immigrant students with a high-quality education. Phi Delta Kappan, 97(4), 46-50.

Lemke, J. (2007). Video epistemology in-and-outside the box: Traversing attentional spaces. In R. Goldman, R. Pea, B. Barron \& S. Derry (Eds.), Video research in the learning sciences (pp. 39-52). London: Erlbaum.

Liang, X. (2012). Language as investment, capital, and economics: Spanish-speaking English learners' language use and attitudes. International Journal of English Linguistics, 2(6), 1-16. doi:10.5539/ijel.v2n6p1

Marshall, C., \& Rossman, G. (2006). Designing qualitative research (4th ed.). London: Sage.

Márque, J., Peña, C., Jones, L., Orange, A., \& Simieou, F. (2018). Academic success and resiliency factors: A case study of unaccompanied immigrant children. American Journal of Qualitative Research, 2(1), 162-181.

Mays, L. (2008). The cultural divide of discourse: Understanding how English-language learners' primary discourse influences acquisition of literacy. The Reading Teacher, 61(5), 415-418. Retrieved from https://www.jstor.org/stable/20204605?seq=1\#page_scan_tab_contents

Merriam, S. (2009). Qualitative research: A guide to design and implementation (Revised and expanded from 'Qualitative research and case study applications in education'). Hoboken, NJ: Jossey-Bass (Wiley).

Merriam, S. B. (1998). Case study research in education: A qualitative approach. San Francisco: Jossey-Bass.

Miles, M. B., \& Huberman, M. (1994). Qualitative Data Analysis. Thousand Oaks, CA: SAGE.

Miller, K. F., \& Zhou, X. (2007). Learning from classroom video: What makes it compelling and what makes it hard. In R. Goldman, R. Pea, B. Barron, \& S. J. Derry (Eds.), Video research in the learning sciences (pp. 321-334). Mahwah, NJ: Erlbaum.

Niehaus, K., \& Adelson, J. L. (2014). School support, parental involvement, and academic and social-emotional outcomes for English language learners. American Educational Research Journal, 51(4), 810-844. doi:10.3102/0002831214531323

Noguera, P. A. (2004). Social capital and the education of immigrant students: Categories and generalizations. Sociology of Education, 77(2), 180-183. doi:10.1177/003804070407700206

OECD. (2015). Helping immigrant students to succeed at school - and beyond. Retrieved from: https://www.oecd.org/education/Helping-immigrant-students-to-succeed-at-school-and-beyond.pdf

Ogbu, J. U., \& Simons, H. D. (1998). Voluntary and involuntary minorities: A cultural-ecological theory of school performance with some implications for education. Anthropology \& Education Quarterly, 29, 155-188. doi:10.1525/aeq.1998.29.2.155

Orfield, G., Frankenberg, E. D., \& Lee, C. (2003). The resurgence of school segregation. Educational Leadership, 60(4), 16-20. Retrieved from https://eric.ed.gov/?id=EJ659146

Park, H. (2018). Influences of reading online texts in Korean English language learners' cultural identities. The Journal of Educational Research, 111(4), 385-397. doi:10.1080/00220671.2017.1284038 
Pollock, D. (2018). Using cultural capital in the ESL classroom: One teacher's journey. Issues in Language Instruction, 7 (1).

Portes, A., \& Rumbaut, R. G. (2001). Legacies: The story of the immigrant second generation. Berkeley: University of California Press.

Rudd, T. (2003). ICT and the reproduction of inequalities: a Bourdieuian perspective . (PhD thesis). Graduate School of Education, University of Bristol.

Short, D. J., \& Boyson , B. A. (2003). Secondary school newcomer programs in the United States. Center for Research on Education, Diversity \& Excellence. doi:10.1.1.488.91\&rep=rep1\&type=pdf|

Straubhaar, R. (2013). Student use of aspirational and linguistic social capital in an urban immigrant-centered English immersion high school. The High School Journal, 97(2), 92-106. doi:10.1353/hsj.2013.0026

St. John, E. P., Hu, S., \& Fisher, A. S. (2011). Breaking through the access barrier: Academic capital formation informing public policy. New York: Routledge.

Suarez-Orozco, M. M. (1987). "Becoming somebody": Central American immigrants in US inner-city schools. Anthropology \& Education Quarterly, 18(4), 287-299. doi:10.1525/aeq.1987.18.4.04x0020t

Tang, S. (2015). Social capital and determinants of immigrant family educational involvement. The Journal of Educational Research, 108(1), 22-34. doi:10.1080/00220671.2013.833076

Thomas, G. (2012). How to do your case study-a guide for students and researchers. London: SAGE Publications.

Trueba, H,. T. (2002). Multiple ethnic, racial, and cultural identities in action: From marginality to a new cultural capital in modern society. Journal of Latinos and education, 1(1), 7-28. doi:10.1207/S1532771XJLE0101_2

U.S. Department of Education, Office of English Language Acquisition (2017). English Learner Tool Kit. Washington, DC: Author.

U.S. Department of Education, Office of English Language Acquisition. (2017). Newcomer Tool Kit. Washington, DC: Author.

Valenzuela, A., \& Rubio, B. (2018). Subtractive schooling. The TESOL Encyclopedia of English Language Teaching. doi:10.1002/9781118784235.eelt0139

Wagner, C. L., \& Gimenez, M. E. (2008). Does community-based collaborative resource management increase social capital? Society and Natural Resources, 21(4), 324-344. doi:10.1080/08941920701864344

Yin, R. K. (2009). Case study research: Design and methods. Thousand Oaks, CA: SAGE Publications.

Zhou, M., \& Bankston, C. L. (1996). The ethnic church, ethnic identification, and the social adjustment of Vietnamese adolescents. Review of Religious Research, 38(1), 18-37. doi:10.2307/3512538 